\author{
ADAM MIKA \\ Uniwersytet Wrocławski \\ e-mail: adam.mika@uwr.edu.pl
}

\title{
Znaczenie Biuletynu Informacji Publicznej w zapewnieniu jawności działań administracji publicznej na przykładzie zamówień publicznych
}

\section{Wstęp}

Realizacja przyjętego w Polsce modelu demokratycznego państwa prawnego wymaga wielu ograniczeń władzy publicznej. Jednym z nich jest zapewnienie szerokiej jawności i transparentności jej działań, co w założeniu ma gwarantować łatwy dostęp do wiedzy o sprawach publicznych. Tylko bowiem obywatele świadomi są w stanie w sposób efektywny kontrolować władzę publiczną oraz decydować o odpowiedzialności osób ją wykonujących. Stanowi to realizację najważniejszej zasady konstytucjonalizmu demokratycznego, tj. suwerenności narodu ${ }^{1}$.

Jawność działań władzy publicznej jest także jednym z głównych postulatów w koncepcji rządu otwartego ${ }^{2}$ oraz w modelu zarządzania sektorem publicznym, tzw. dobrym rządzeniu (good governance) $)^{3}$.

W demokratycznym państwie prawnym obowiązek jawności działań będzie w dużej mierze spoczywać na administracji publicznej. Decyduje o tym funkcja, do której została ona wyznaczona, czyli wykonywanie zadań publicznych z wykorzystywaniem do tego celu publicznych funduszy. Transparentność ogranicza również stronnicze i nieetyczne działania wewnątrz organów administracyjnych ${ }^{4}$.

${ }^{1}$ Komentarz (art. 61), [w:] B. Banaszak, Konstytucja Rzeczypospolitej Polskiej, Warszawa 2012, Legalis, nb. 4.

2 Ibidem, nb. 3.

3 W. Szumowski, Zarządzanie publiczne - próba systematyzacji koncepcji, „Nauki o Zarządzaniu - Management Sciences" 2014, nr 4 (21), s. 95.

${ }^{4}$ B. Kudrycka, Dylematy urzędników administracji publicznej, Białystok 1995, s. 93. 


\section{Biuletyn Informacji Publicznej jako gwarancja jawności działań władzy publicznej}

Zasada jawności działań władzy publicznej jest nieodzownie związana z konstytucyjnym prawem do informacji publicznej, wyrażonym w art. 61 ust. 1 Konstytucji RP, zgodnie z którym obywatel ma prawo do uzyskiwania informacji o działalności organów władzy publicznej oraz osób pełniących funkcje publiczne. Konkretyzacja tego prawa nastąpiła głównie w drodze uchwalenia ustawy o dostępie do informacji publicznej ${ }^{5}$, regulującej zasady i tryb jego realizacji. Ważną rolę w powszechnym zapewnieniu dostępu do informacji publicznej odgrywa utworzony na podstawie u.d.i.p. Biuletyn Informacji Publicznej (BIP). Jest to publikator teleinformatyczny, funkcjonujący w postaci ujednoliconego systemu stron internetowych. Opublikowane w nim informacje są dostępne dla odwiedzających nieprzerwanie i bezpłatnie poprzez stronę główną: www.bip.gov.pl oraz poprzez tzw. strony podmiotowe, prowadzone przez organy administracji publicznej, jednostki samorządu terytorialnego oraz inne podmioty zobowiązane do udzielania informacji publicznych. Niewątpliwą zaletą BIP jest jego przejrzystość w obsłudze i łatwy dostęp za pomocą każdego urządzenia mającego połączenie z Internetem.

\section{Zasada jawności w procesie udzielania zamówień publicznych}

Dokonywanie zakupów przez państwo, w tym przez jego poszczególne organy, zawsze było związane z wydatkowaniem publicznych środków finansowych ${ }^{6}$. Współcześnie problematyka ta określana jest jako „zamówienia publiczne”. Przedmiot zamówień jest różnorodny w zależności od rodzaju zamawiającego, jego kompetencji i potrzeb. Mogą one dotyczyć zarówno powierzania zadań publicznych wykonywanych przez administrację ${ }^{7}$, jak i wewnętrznych dostaw realizowanych w celu polepszenia wyposażenia danego podmiotu. Poszczególne zamówienia różnią się między sobą wartością, niektóre szacowane są na kilkadziesiąt tysięcy złotych, inne - takie jak np. strategiczne kontrakty infrastrukturalne - liczone są w miliardach euro. Mając to na uwadze, niezwykle ważne jest zapewnienie jawności działań państwa (w tym przede wszystkim administracji rządowej i samorządowej) także w tym obszarze.

5 Ustawa z dnia 6 września 2001 r. o dostępie do informacji publicznej (Dz.U. z 2016 r. poz. 1764; z 2017 r. poz. 933; dalej: u.d.i.p.).

6 System zamówień publicznych w Polsce, red. J. Sadowy, Warszawa 2013, s. 15.

7 Przykładem może tu być odbiór odpadów komunalnych, o którym mowa w art. 6c Ustawy z dnia 13 września 1996 r. o utrzymaniu czystości i porządku w gminach (Dz.U. z 2017 r. poz. 1289). 
W polskim systemie prawa główny akt normujący wskazaną materię to ustawa - Prawo zamówień publicznych ${ }^{8}$. Przywołany akt prawny w art. 8 wprowadza jedną z naczelnych zasad, tj. jawności postępowania, która $\mathrm{w}$ założeniu stanowi uzupełnienie postanowień ustawy o dostępie do informacji publicznej ${ }^{9}$. Realizacja tej zasady przejawia się w wielu poszczególnych przepisach p.z.p. Jej odzwierciedlenia można dopatrzyć się chociażby w zobowiązaniu zamawiającego do otwarcia ofert przy udziale wszystkich zainteresowanych (art. 86 ust. 4 p.z.p.), należytego dokumentowania postępowania (art. 96-98 p.z.p.) czy w końcu zapewnienia dostępu do zawartych umów (art. 139 ust. 3 p.z.p.) ${ }^{10}$. Jawność postepowania o udzielenie zamówienia publicznego przede wszystkim gwarantowana jest jednak przez publikację wymaganych ustawą ogłoszeńn ${ }^{11}$.

$\mathrm{W}$ art. 11 p.z.p. przewidziane zostały dwa główne publikatory wykorzystywane w tym celu. Pierwszym z nich jest Biuletyn Zamówień Publicznych (BZP) prowadzony przez Prezesa Urzędu Zamówień Publicznych, drugi to Dziennik Urzędowy UE. Wybór właściwego miejsca publikacji jest zależny od rodzaju, a przede wszystkim wartości danego kontraktu. Kluczową rolę ogrywają w tym zakresie tzw. progi unijne, o których mowa w art. 11 ust. 8 p.z.p. Ogłoszenia dotyczące zamówień o wartości przekraczającej bądź równej kwotom progowym przekazuje się do publikacji w Dzienniku Urzędowym UE. Wynika to głównie z faktu, że zamówienia publiczne stanowią ważną część rynku wspólnego, a udział w postępowaniu powinien być zapewniony na równych zasadach dla wykonawców ze wszystkich krajów członkowskich Unii Europejskiej. Przy umowach o mniejszej wartości zamawiający samodzielnie udostępnia ogłoszenia w elektronicznym BZP na stronach portalu Urzędu Zamówień Publicznych.

Pomimo istnienia dwóch podstawowych publikatorów ustawodawca zdecydował, że niektóre rodzaje ogłoszeń w procesie udzielenia zamówienia publicznego będą publikowane w innym miejscu, tj. w Biuletynie Informacji Publicznej.

\section{Biuletyn Informacji Publicznej w ustawie — Prawo zamówień publicznych}

W pierwotnej wersji p.z.p. w ogóle nie przewidywano jakichkolwiek obowiązkowych publikacji w BIP. Zmieniło się to dopiero w kolejnych latach, kiedy wprowadzono obowiązek udostępnienia informacji o postępowaniu kwalifikacyjnym na członków Krajowej Izby Odwoławczej (KIO) na stronie BIP Urzędu Za-

${ }^{8}$ Ustawa z dnia 29 stycznia 2004 r. — Prawo zamówień publicznych (Dz.U. z 2015 r. poz. 2164 ze zm.; dalej: p.z.p.).

9 P. Granecki, Prawo zamówień publicznych. Komentarz, Warszawa 2016, s. 172.

10 Ibidem, s. 173.

11 System zamówień publicznych..., s. 106. 
mówień Publicznych oraz Kancelarii Prezesa Rady Ministrów oraz przewidziano podobną regulację dotyczącą naboru na stanowisko Prezesa Zamówień Publicznych $^{12}$. Pomimo kolejnych nowelizacji wykorzystanie BIP w p.z.p. było jednak znikome i związane jedynie z problematyką doboru kadr. Istotne zmiany w tym zakresie przyniosła dopiero tzw. duża nowelizacja z 2016 r. ${ }^{13} \mathrm{~W}$ wyniku wprowadzonych przez nią zmian obowiązek publikacji w BIP po raz pierwszy został rozszerzony na samą procedurę udzielania zamówień publicznych. Ma to obecnie miejsce w dwóch przypadkach: pierwszy z nich dotyczy tzw. zamówień in-house, drugi — zamówień na usługi społeczne.

\section{Zamówienia in-house}

Zamówienia in-house, zwane też „zamówieniami bezpośrednimi”, klasyfikowane są jako rodzaj nietypowych umów ${ }^{14}$. Ich regulacja stanowi novum w p.z.p. W pewnym uproszczeniu są to zamówienia zawieranie między formalnie odrębnymi od siebie podmiotami publicznymi, które pozostają jednak w relacji silnej zależności. Ustawodawca zdecydował się w art. 67 ust. 1 pkt $12-15$ p.z.p. (w każdym punkcie osobno) na uregulowanie czterech rodzajów zamówień in-house. Nie wchodząc w szczegóły, dla odróżnienia można je nazwać: klasycznymi, odwróconymi, łącznymi i wdrażającymi współpracę między zamawiającymi w celu wykonania usług publicznych ${ }^{15}$.

Modelowym przykładem zamówień bezpośrednich są te uregulowane w art. 67 ust. 1 pkt 12 p.z.p. (klasyczne). Mogą być one udzielone jedynie przez ograniczony krąg zamawiających, którymi są głównie jednostki sektora finansów publicznych (m.in. organy administracji publicznej, jednostki samorządu terytorialnego) i tzw. podmioty publiczne. Ich wykonawcą może być z kolei jedynie osoba prawna. Oprócz istotnego zawężenia katalogu podmiotów będących stronami umowy, ustawodawca przewidział jeszcze trzy dodatkowe przesłanki wymagane łącznie, bez których udzielenie zamówienia in-house nie będzie możliwe. Są to:

1) sprawowanie kontroli przez zamawiającego nad wykonawcą, która odpowiada kontroli nad własnymi jednostkami — rozumie się przez to wywieranie dominującego wpływu na cele strategiczne oraz istotne decyzje wykonawcy w kwestii zarządzania jego sprawami;

12 Odpowiednio art. 176a i 153 p.z.p.

13 Ustawa z dnia 22 czerwca 2016 r. o zmianie ustawy - Prawo zamówień publicznych oraz niektórych innych ustaw (Dz.U. z 2016 r. poz. 1020; dalej: duża nowelizacja z 2016 r.).

14 System zamówień publicznych..., s. 85.

15 Zamówienia na roboty budowlane, ustugi, dostawy w systemie in-house, red. J. Pawelec, Warszawa 2016, s. 153-165. 
2) ponad $90 \%$ działalności kontrolowanej osoby prawnej dotyczy wykonywania zadań powierzonych jej przez zamawiającego sprawującego kontrolę;

3) w kontrolowanej osobie prawnej nie ma bezpośredniego udziału kapitału prywatnego.

Przykładem takiego zamówienia może być świadczenie usług porządkowych przez gminną spółkę komunalną.

Zamówienia in-house są udzielane w trybie wolnej ręki, a więc najmniej konkurencyjnym spośród wszystkich przewidzianych przez ustawę. Stosowanie go powinno zatem następować wyjątkowo, po uprzednim zbadaniu możliwości zastosowania innych trybów konkurencyjnych, takich jak np. tryby negocjacyjne ${ }^{16}$. Jak stanowi art. 66 ust. 1 p.z.p., zamówienie $\mathrm{z}$ wolnej ręki to tryb udzielenia zamówienia, w którym zamawiający udziela zamówienia po negocjacjach tylko z jednym wykonawcą. Nie wymaga zatem ani ogłoszenia o zamówieniu, ani stworzenia specyfikacji istotnych warunków zamówienia. Działający na rynku potencjalni wykonawcy mogą często nawet nie wiedzieć, że dane postępowanie w ogóle się toczy. Co prawda, ustawa przewiduje możliwość publikacji w BZP lub Dzienniku Urzędowym UE informacji o zamiarze zawarcia umowy w trybie z wolnej ręki, lecz nie jest to działanie obowiązkowe.

Zarówno wszystkie przedstawione okoliczności, jak i bliskie powiązania zamawiającego i wykonawcy rodzą potencjalne ryzyko nadużywania instytucji zamówień in-house. Aby temu zapobiec, ustawodawca zdecydował się nałożyć na zamawiającego dodatkowy obowiązek w celu zapewnienia transparentności jego działań. Został on wyrażony w art. 67 ust. 11 p.z.p. i polega na obligatoryjnym powiadomieniu o każdorazowym zamiarze udzielenia zamówienia bezpośredniego na swojej stronie podmiotowej BIP ${ }^{17}$. Ogłoszenie powinno pojawić się już po przeprowadzeniu negocjacji z potencjalnym wykonawcą, ale jeszcze przed zawarciem umowy ${ }^{18}$, oraz zawierać - co najmniej — następujące informacje:

1) nazwę i adres zamawiającego;

2) określenie przedmiotu zamówienia i wielkości lub zakresu zamówienia;

3) szacunkową wartość zamówienia;

4) nazwę i adres wykonawcy, któremu zamawiający zamierza udzielić zamówienia;

5) podstawę prawną i uzasadnienie wyboru trybu udzielenia zamówienia $\mathrm{z}$ wolnej ręki;

6) planowany termin realizacji zamówienia i czas trwania umowy;

7) informację o terminie i odpowiednio zamieszczeniu lub opublikowaniu ogłoszenia o zamiarze zawarcia umowy w BZP (Dzienniku Urzędowym UE), je-

16 Wyrok KIO z dnia 20 maja 2010 r., sygn. KIO 754/10, Legalis nr 323041.

17 Zgodnie z przepisem, jeżeli zamawiający nie prowadzi takiej strony, powinien zamieścić ogłoszenie na swojej stronie internetowej.

18 Zamówienia na roboty..., s. 134. 
żeli zostało zamieszczone lub opublikowane, albo informację, że takie ogłoszenie nie zostało zamieszczone lub opublikowane.

Zakres ogłoszenia jest na tyle szeroki, by potencjalni zainteresowani mogli dostatecznie zweryfikować, co w danym przypadku jest przedmiotem umowy, czy byliby w stanie wykonać zamówienie, czy staraliby się o nie w procedurze konkurencyjnej oraz czy w ogóle istnieją przesłanki do udzielenia zamówienia bezpośredniego.

Zgodnie z art. 67 ust. 13 p.z.p. w BIP powinna się również znaleźć informacja o ostatecznie udzielonym lub nieudzielonym zamówieniu in-house.

\section{Zamówienia na usługi społeczne}

Drugim rodzajem postępowania o udzielenie zamówienia publicznego, w którym duże znaczenie zaczął odgrywać Biuletyn Informacji Publicznej, jest postępowanie w sprawach tzw. zamówień na usługi społeczne, które po nowelizacji z 2016 r. pojawiły się w miejscu tzw. usług niepriorytetowych ${ }^{19}$. Charakteryzują się one ograniczonym znaczeniem transgranicznym, w związku z czym są wykonywane głównie przez podmioty funkcjonujące na lokalnym rynku. Wynika to przede wszystkim z ich specyfiki. Zamówienia na usługi społeczne dotyczą bowiem takich sfer, jak usługi religijne, zdrowotne, niektóre usługi prawne, ochroniarskie czy restauracyjne. Zagraniczni wykonawcy nie są z reguły nimi zainteresowani z uwagi na konieczność poniesienia sporych nakładów, które niekoniecznie przekładałyby się na późniejsze zyski. Regulacje dotyczące usług społecznych stanowią zatem próbę odformalizowania zamówień publicznych w dziedzinach, w przypadku których konkurencja wykonawców zabiegających o kontrakt jest $\mathrm{z}$ reguły ograniczona.

Zamówienia na usługi społeczne ze względu na ich wartość dzieli się na tzw. zamówienia nadprogowe i podprogowe ${ }^{20}$. W wypadku tych pierwszych wartość musi przekraczać bądź być przynajmniej równa przeliczonej na złote równowartości 750 tys. euro w przypadku zamówień klasycznych albo $1 \mathrm{mln}$ euro, jeżeli mamy do czynienia z zamówieniami sektorowymi. Zamówienia nadprogowe cechują się pewnym ograniczonym formalizmem. Odpowiednio stosuje się do nich znaczną część przepisów dotyczących zamówień klasycznych, m.in. w zakresie ustalania warunków udziału w postępowaniu, opisu przedmiotu zamówienia oraz wykluczenia wykonawcy. Zachowany został również obowiązek wyłączenia się

19 Podział na usługi priorytetowe i niepriorytetowe pozostał aktualny w dziedzinach obronności i bezpieczeństwa - art. 131 bb p.z.p.

20 Proces udzielania zamówień publicznych po nowelizacji Prawa zamówień publicznych, red. M. Śledziewska, Warszawa 2017, s. 295-296. 
z postępowania osób występujących po stronie zamawiającego, jeśli ich bezstronność jest wątpliwa.

Jeszcze mniejszy formalizm towarzyszy zamówieniom podprogowym, które konsekwentnie będą miały wartość odpowiednio mniejszą niż równowartość 750 tys. i 1 mln euro. W stosunku do nich ustawodawca określił jedynie dwa obowiązki. Pierwszym z nich jest zachowanie przez zamawiającego ogólnych reguł przejrzystości, obiektywności i niedyskryminacji. Drugim, szczególnie interesującym w zakresie niniejszej pracy, jest właśnie obowiązek publikacji ogłoszenia o zamówieniu na podmiotowej stronie Biuletynu Informacji Publicznej ${ }^{21}$. Obligatoryjna treść publikacji została jednak w tym wypadku uregulowana w sposób minimalistyczny - ustawa przewiduje jedynie, że ogłoszenie umieszczone w BIP powinno zawierać informacje niezbędne z uwagi na okoliczności udzielenia zamówienia. W szczególności będą to:

1) termin składania ofert, uwzględniający czas niezbędny do przygotowania i złożenia oferty;

2) opis przedmiotu zamówienia oraz określenie wielkości lub zakresu zamówienia;

3) kryteria oceny ofert.

Przedstawiony katalog ma charakter otwarty, co oznacza, że ostateczna treść ogłoszenia może zostać każdorazowo rozbudowana przez zamawiającego w zależności od jego potrzeb, np. o okoliczności uzasadniające wykluczenie wykonawców.

Należy w tym miejscu dodać, że obowiązek publikacji w BIP zastępuje wymóg umieszczenia ogłoszenia o zamówieniu w BZP (Dzienniku Urzędowym UE). W tym publikatorze powinna zostać również umieszczona późniejsza informacja o udzieleniu zamówienia $\mathrm{z}$ wyszczególnieniem stron umowy lub o jego nieudzieleniu.

\section{Konsekwencje niezamieszczenia ogłoszenia w BIP}

W dwóch omawianych przypadkach obowiązek zamieszczania publikacji w BIP jest ważnym elementem procesu udzielenia zamówienia. W związku z tym pojawia się pytanie: jakie konsekwencje nieść będzie za sobą jego zaniechanie? Kwestia ta będzie analizowana zwłaszcza w zakresie wpływu braku ogłoszenia na ważność następnie zawartej umowy.

$21 \mathrm{~W}$ przypadku braku strony podmiotowej BIP ogłoszenie powinno znaleźć się na stronie internetowej zamawiającego. 


\section{Brak publikacji w BIP a zamówienie in-house}

Skutki braku publikacji w BIP dotyczącej zamiaru udzielenia zamówienia bezpośredniego (art. 67 ust. 11 p.z.p.) nie zostały ujęte wprost w p.z.p. Niemniej jednak analiza innych przepisów uzasadnia przyjęcie, że niezamieszczenie takiego ogłoszenia spowoduje konieczność unieważnienia kontraktu. Świadczy o tym dodany dużą nowelizacją z 2016 r. art. 146 ust. 1 pkt 7 p.z.p., stanowiący, że umowa w przedmiocie zamówienia publicznego podlega unieważnieniu, jeśli zamawiający zawarł ją przed upływem terminu, o którym mowa w art. 67 ust. 12 p.z.p. Przywołany art. 67 ust. 12 p.z.p. zawiera tzw. klauzulę standstill, tj. okres zawieszenia, który w każdym wypadku musi upłynąć, zanim zamawiający będzie władny podpisać umowę - wynosi 14 dni od daty ogłoszenia w BIP o zamiarze udzielenia zamówienia in-house.

Należy zatem przyjąć, że jeżeli ogłoszenie to w ogóle nie ukazałoby się w BIP, termin wskazany w art. 67 ust. 12 p.z.p. również nie rozpocząłby biegu. Inna sytuacja jest teoretycznie niemożliwa. Każde zamówienie bezpośrednie udzielone z pominięciem obligatoryjnej publikacji w BIP naruszałaby zatem art. 146 ust. 1 pkt 7 p.z.p., co tym samym stanowi podstawę do jego unieważnienia.

Niniejsza konkluzja pozostaje aktualna także w przypadku publikacji w BIP niekompletnego ogłoszenia, tzw. takiego, które nie zawiera wszystkich pozycji wyszczególnionych w art. 67 ust. 11 p.z.p. Ustawodawca, wyznaczając minimalny katalog obligatoryjnych elementów ogłoszenia, wyraźnie bowiem przesądził, że tworzą one zwartą informację. Niekompletna publikacja nie spełnia swojej roli, nie respektuje też należycie zasady jawności w procesie udzielenia zamówienia in-house. Tym samym nie może zostać uznana za wypełnienie obowiązku przewidzianego przez ustawodawcę. Inaczej należałoby jednak potraktować sytuację, gdy ogłoszenie zawierałoby co prawda wszystkie informacje przewidziane $\mathrm{w}$ art. 67 ust. 11 p.z.p., lecz przykładowo obejmowałoby chybione uzasadnienie pominięcia przez zamawiającego procedur konkurencyjnych. Wówczas powinno się żądać unieważnienia umowy na podstawie nieuzasadnionego wyboru trybu z wolnej ręki na podstawie art. 146 ust. 1 pkt 1 p.z.p.

W związku z tym, że brak ogłoszenia o zamiarze udzielenia zamówienia in-house każdorazowo doprowadzi do unieważnienia umowy na podstawie art. 146 ust. 1 pkt 7 w zw. z art. 67 ust. 12 p.z.p., nie można zgodzić się ze stanowiskiem dopuszczającym w tym przypadku powództwo o ustalenie nieważności stosunku prawnego na podstawie art. 189 k.p.c. w zw. z a contrario art. 146 ust. 4 p.z.p. ${ }^{22}$

Konsekwencje braku ogłoszenia, o którym mowa powyżej, będą różnić się od braku ogłoszenia o zawarciu umowy na podstawie art. 67. ust. 13 p.z.p. W tym drugim przypadku ustawa w żaden sposób nie precyzuje negatywnych skutków zaniechania. Skąpość regulacji można jednak uzasadniać faktem, że rola tej pu-

22 Inaczej: Zamówienia na roboty..., s. 135. 
blikacji nie ma aż tak doniosłego znaczenia. Jak bowiem wynika z art. 95 p.z.p., ogłoszenie o udzieleniu zamówienia jest zawsze obligatoryjnie zamieszczane w BZP (Dzienniku Urzędowym UE). To z naruszeniem tego obowiązku ustawodawca wiąże istotne konsekwencje prawne, m.in. wydłużenie terminu na wniesienie odwołania. Należy zatem uznać, że brak ogłoszenia przewidzianego w art. 67 ust. 13 p.z.p. spowoduje co najwyżej stwierdzenie naruszeń przepisów ustawy podczas ewentualnej kontroli, nie wpłynie jednak na ważność zawartej umowy.

\section{Brak publikacji w BIP a zamówienie na usługi społeczne}

Brak ogłoszenia o zamówieniu, o którym mowa w art. 138o p.z.p., również nie został uregulowany wprost $\mathrm{w}$ ustawie. W związku $\mathrm{z}$ tym, że procedura dotycząca zamówień na podprogowe usługi społeczne jest ustalana autonomicznie przez każdego zamawiającego (z obowiązkowym zachowaniem jej przejrzystości, obiektywności i niedyskryminacji), nie znajdzie tutaj zastosowania instytucja unieważnienia umowy, przewidziana w art. 146 p.z.p. Stanowisko to potwierdza dodatkowo fakt, że przesłanki wyszczególnione w tym artykule nie odnoszą się do publikacji w BIP; jednocześnie nie powinny podlegać też wykładni rozszerzającej ${ }^{23}$. Stanowią bowiem znaczną ingerencję w trwałość umów i pewność obrotu.

Na marginesie warto tylko wspomnieć, że jeszcze przed dużą nowelizacją z 2016 r. Krajowa Izba Odwoławcza wyrażała stanowisko, że brak zamieszczania ogłoszeń na stronie internetowej, w siedzibie zamawiającego czy właśnie w Biuletynie Informacji Publicznej nie może stanowić podstawy do unieważnienia zamówienia publicznego ${ }^{24}$. Warto również wskazać, że zgodnie z opinią prawną opublikowaną na stronie internetowej Urzędu Zamówień Publicznych (UZP) w sprawach dotyczących podprogowych zamówień na usługi społeczne nie przysługuje odwołanie do KIO ani skarga do Sądu Okręgowego ${ }^{25}$. Zatem nawet w przypadku naruszenia przepisów p.z.p. nie będzie możliwe skuteczne wniesienie środka zaskarżenia.

Mając powyższe na uwadze, należy uznać, że jedyną dopuszczalną drogą zmierzającą do zakwestionowania ważności udzielenia zamówienia byłoby wniesienie powództwa o ustalenie nieważności umowy na podstawie art. 189 k.p.c. Brak ogłoszenia o zamówieniu stanowiłby w takim założeniu jawne naruszenie art. 1380 ust. 3 p.z.p. Ponadto nie sposób przyjąć, żeby jakakolwiek procedura bez zachowania obowiązku publikacji spełniałaby wymóg przejrzystości określony w art. 1380 ust. 2 p.z.p. Jednocześnie nie można zapominać, że art. 138 o p.z.p. ma charakter ius

23 Wyrok Krajowej Izby Odwoławczej (dalej: KIO) z dnia 17 czerwca 2013 r., sygn. KIO 1307/13, Legalis nr 743425.

24 Wyrok KIO z dnia 16 lutego 2015 r., sygn. KIO 229/15, Legalis nr 1218932.

25 http://www.uzp.gov.pl/baza-wiedzy/interpretacja-przepisow/pytania-i-odpowiedzi-dotyczące-nowelizacji-ustawy-prawo-zamowien-publicznych/usługi-spoleczne-i-inne-szczegolne-uslugi (dostęp: 24.07.2017). 
cogens i nie sposób wyłączyć jego obowiązywania. W związku z tym udzielenie zamówienia z naruszeniem wskazanej regulacji jest sprzeczne z prawem, a co za tym idzie — nieważne na podstawie art. $58 \S 1$ k.c. w zw. z art. 14 p.z.p.

Niejasna jest jednak konsekwencja naruszenia obowiązku niezwłocznego zamieszczenia na stronie podmiotowej BIP informacji o udzieleniu zamówienia. Wydaje się, że jakiekolwiek próby podważania wyboru wykonawcy wyłącznie w oparciu o brak takiej publikacji byłyby skazane na porażkę. Podobnie jak w przypadku art. 67 ust. 13 p.z.p., niedopełnienie obowiązku z art. 1380 ust. 4 p.z.p. może głównie zaważyć na ocenie przeprowadzenia postępowania w razie ewentualnej kontroli.

\section{Wnioski}

Biuletyn Informacji Publicznej pełni ważną rolę w zapewnieniu dostępu do informacji publicznej, tym samym w dużej mierze gwarantuje obowiązywanie zasady jawności działania władzy publicznej, w tym m.in. administracji rządowej i samorządowej. Po ostatniej dużej nowelizacji p.z.p. w 2016 r. pełni on również zauważalną rolę $\mathrm{w}$ procesie udzielania zamówień publicznych. BIP stał się bowiem publikatorem w procesie udzielania dwóch specyficznych typów zamówień, $\mathrm{tj}$. in-house i na usługi społeczne.

Należy przy tym zauważyć, że rola BIP $\mathrm{w}$ obu tych przypadkach nie jest tożsama. W pierwszym z nich wymóg publikacji o zamiarze udzielenia zamówienia in-house stanowi dodatkowy obowiązek zamawiającego. Inaczej wygląda rola publikacji BIP dotycząca podprogowych zamówień na usługi społeczne. Zastępuje ona bowiem ogłoszenie o zamówieniu, które w zamówieniach klasycznych zamieszcza się w głównych publikatorach wskazanych przez ustawę, tj. BZP i Dzienniku Urzędowym UE.

Odmienna rola ogłoszenia w BIP w ramach analizowanych wypadków znajduje także odzwierciedlenie w regulacjach sankcjonujących jego brak. Jeżeli chodzi o zamówienia in-house, umowa co do zasady ulegnie unieważnieniu w związku z naruszeniem przez zamawiającego klauzuli standstill, o której mowa w art. 67 ust. 12 p.z.p. Z kolei w sytuacji zaniechania ogłoszenia o zamówieniu na podprogowe usługi społeczne ustawodawca nie przewidział podobnej regulacji. Jedyną dopuszczalną drogą kwestionowania ważności takiej umowy będzie wniesienie powództwa o ustalenie nieważności na podstawie art. 189 k.p.c. Doniosłych konsekwencji prawnych nie będzie w tym zakresie nieść za sobą zaniechanie ogłoszenia o udzieleniu zamówienia in-house i na podprogowe usługi społeczne.

O ile obowiązek publikacji w BIP ogłoszenia, o którym mowa w art. 67 ust. 11 p.z.p., powinien doprowadzić do zwiększenia gwarancji jawności działań władzy publicznej, o tyle nie jest to już takie oczywiste w przypadku publika- 
cji dotyczącej zamówień na podprogowe usługi społeczne. Wniosek ten wynika $\mathrm{z}$ ograniczenia treści ogłoszenia w BIP jedynie do podstawowych informacji oraz nieuregulowania explicite skutków braku jego publikacji. Rodzi to potencjalne pole do nadużyć, tym bardziej jeśli weźmie się pod uwagę, że wartość takich zamówień nierzadko będzie liczona w milionach złotych.

\section{The importance of Public Information Bulletin (BIP) for realizing transparency of public administration activities in public procurement area}

\section{Summary}

Public Information Bulletin (BIP) has a great influence on direct access to public information. Its importance is bigger and bigger in Public Procurement Law nowadays. Publications in BIP are currently required in cases of in house-procurement and public contracts for social and other specific services. The aim of this paper is to evaluate the impact of BIP on transparency of public administration activities in public procurement area, especially the impact of the lack of publication in BIP on validity of contracts.

Keywords: Public Information Bulletin, public procurement, house-procurement, transparency, public administration. 